\title{
ANALISIS KELAYAKAN EKONOMI BERBAGAI SISTEM SADAP PADA PANEL BO TANAMAN KARET (STUDI KASUS KEBUN BATU JAMUS, JAWA TENGAH)
}

\author{
Economic Feasibility Analysis of Various Tapping Systems On the Bark Original \\ Panel of Rubber Plant (Case Study at Batujamus Estate, Central Java) \\ Titik WIDYASARI*, Mudita Oktorina NUGRAHANI, Akhmad ROUF, \\ Yoga Bagus Setya AJI, dan Nofitri Dewi RINOJATI \\ Balai Penelitian Getas, Pusat Penelitian Karet \\ Jl. Patimura KM 6 PO BOX 804 Salatiga 50702 Jawa Tengah \\ *Email : titikwidyasari@gmail.com
}

Diterima : 9 Juni 2017 / Disetujui : 20 Februari 2018

\begin{abstract}
Rubber price fluctuation is a phenomenon that can not be avoided, however, rubber businessmen constantly trying to maintain to lower production costs and increased estate productivity. One of the efforts is the reduction of tapping frequency. This research aims to analyze how the financial feasibility of various tapping systems on BO panel with frequency tapping variation and stimulants that are expected to reduce costs and tapper usage. The experiment was conducted in Batujamus estate, since Oktober 2015 until October 2016. The experiment was arranged in Randomized Complete Block Design, with 11 treatments tapping systems and 3 replications. Partial budget analysis was used to measure the economical feasibility. Result of the research showed that the tapping system which economically feasible to apply are tapping system $S / 2 d 3 . E T 2,5 \% . G a .1 . m / 3$, $S / 2 d 3 . E T 2,5 \% . G a .1 .2 w$, $S / 2 d 3 . E T 4,0 \%$. G a . 1 . $2 w$, $S / 2 d 4 . E T 4,0 \% . G a .1 .2 w$ and S/2d4.ET5,0\%.Ga.1.2w.
\end{abstract}

Keywords: BO panel; economic feasibility; rubber plant; tapping system

\begin{abstract}
Abstrak
Fluktuasi harga karet merupakan fenomena yang tidak dapat dihindari, namun pebisnis karet senantiasa berusaha bertahan agar biaya produksi rendah dan produktivitas kebun meningkat. Salah satu usaha yang dilakukan adalah penurunan
\end{abstract}

frekuensi sadap. Penelitian ini bertujuan untuk menganalisis kelayakan ekonomi berbagai sistem sadap di panel BO dengan variasi frekuensi sadap dan stimulansia yang diharapkan mampu menurunkan biaya penyadapan dan penggunaan tenaga penyadap. Penelitian dilaksanakan di Kebun Batujamus milik perusahaan negara mulai Oktober 2015 hingga Oktober 2016. Penelitian disusun dengan Rancangan Acak Kelompok Lengkap dengan 11 perlakuan sistem sadap dan 3 ulangan. Analisis anggaran parsial digunakan untuk menilai kelayakan ekonomi. Hasil penelitian menunjukkan bahwa sistem sadap yang layak untuk diterapkan adalah sistem sadap S / 2d 3.ET 2.5\%.G a.1.m / 3, S/ 2 d 3. E T 2.5\%.G a . 1.2 w, S / 2 d 3.E T $4.0 \%$. G a.1.2 w, S/ 2 d 4.E T 4.0\%.Ga.1.2 w dan S/2 d4.ET5.0\%.Ga.1.2w.

Kata kunci: Kelayakan ekonomi; panel BO; sistem sadap; tanaman karet

\section{PENDAHULUAN}

Pada periode tiga tahun terakhir telah terjadi fenomena penurunan harga berbagai komoditas yang sangat signifikan di pasar internasional termasuk komoditas karet. Harga karet tertinggi dicapai pada tahun 2011 hingga di atas USD 4,5 per Kg selebihnya berada di bawah USD 2,5 per Kg. Harga karet terus mengalami penurunan hingga hampir menyentuh USD 1 per $\mathrm{Kg}$ pada tahun 2016 (Pusat Penelitian Karet (Puslit Karet), 2016). Pada awal tahun 2017, harga mampu merangkak naik mendekati angka USD 3 per $\mathrm{kg}$ dan kemudian turun 
lagi. Fluktuasi harga karet tentunya sangat berpengaruh terhadap stabilitas perkebunan karet. Semua pebisnis karet berusaha untuk menekan biaya produksi dan meningkatkan produktivitas agar mampu mencapai kondisi surplus. Salah satu upaya yang dilakukan adalah menerapkan sistem sadap yang sesuai dengan kondisi pada saat itu. Bagi tanaman karet (Hevea brasiliensis Muell. Arg), produktivitas tanaman karet menjadi tolok ukur potensi ekonomi kebun atau menentukan tingkat profitabilitas perusahaan.

Ciri khas pengusahaan perkebunan karet adalah pada cara panennya yaitu dengan mengiris kulitnya untuk memperoleh lateks yang disebut penyadapan. Penyadapan sampai saat ini dilakukan secara manual oleh tenaga penyadap dan belum ada teknologi mekanisasi yang handal untuk mempermudah proses penyadapan. Oleh karena itu dibutuhkan tenaga terampil dalam melaksanakan kegiatan penyadapan. Kenyataannya, hampir semua perkebunan mengalami kekurangan tenaga penyadap yang ahli dan terampil. Di Jawa Barat, terdapat kekurangan tenaga penyadap 17 orang/hari sampai dengan 300 orang/hari (Rouf, Nugrahani, \& Aji, 2016) sehingga ketersediaan tenaga penyadap menjadi faktor pembatas dalam pengusahaan perkebunan karet. Dari segi biaya produksi, komposisi biaya produksi terbesar adalah untuk pemanenan dan pemupukan tanaman menghasilkan (TM) (Widyasari, Hartono \& Irham, 2015). Penyadapan merupakan komponen biaya produksi terbesar (Rodrigo, 2007) yang mencapai 33\% sampai dengan 44\% FOB sehingga selalu menjadi perhatian utama jika terjadi perubahan harga komoditas (Sumarmadji, Junaidi, \& Atminingsih, 2009).

Berbagai alternatif dilakukan untuk menurunkan biaya penyadapan dan mengatasi kesulitan penyediaan tenaga kerja penyadap, antara lain dengan mengurangi frekuensi sadap dan penggunaan stimulansia. Penggunaan stimulansia dapat digunakan untuk meningkatkan produksi lateks saat frekuensi sadap dikurangi. Stimulan meningkatkan produksi lateks dengan cara memperlama aliran karena penyumbatan pembuluh lateks terhambat (Krishnakumar et al., 2011 dalam ${ }^{\mathrm{a}}$ Herlinawati \& Kuswanhadi, 2012). Setiap klon mempunyai frekuensi optimum stimulasi yang berbeda untuk menghasilkan produksi tertinggi sesuai dengan karakter fisiologi ('Herlinawati \& Kuswanhadi, 2012). Tulisan ini bertujuan menganalisis kelayakan ekonomi berbagai sistem sadap di panel BO dengan variasi frekuensi sadap dan stimulansia yang diharapkan mampu menurunkan biaya penyadapan dan penggunaan tenaga penyadap.

\section{BAHAN DAN METODE}

Penelitian dilaksanakan di Afdeling Kedung Sumber, Kebun Batujamus milik perusahaan negara sejak Oktober 2015 hingga Oktober 2016. Klon PB 260 tahun tanam 2005 digunakan sebagai objek yang diamati. Penelitian disusun dengan Rancangan Acak Kelompok Lengkap (RAKL) dengan 11 perlakuan sistem sadap dan 3 ulangan. Tiap plot terdiri atas 10 pohon. Masing-masing perlakuan yang disusun sebagai berikut:

$\mathrm{A}=\mathrm{S} / 2 \mathrm{~d} 2$ (kontrol)

$\mathrm{B}=\mathrm{S} / 2 \mathrm{~d} 3 . \mathrm{ET} 2,5 \% \cdot \mathrm{Ga} \cdot 1.2 \mathrm{w}$

$\mathrm{C}=\mathrm{S} / 2 \mathrm{~d} 3 . \mathrm{ET} 4,0 \% \cdot \mathrm{Ga} \cdot 1.2 \mathrm{w}$

$\mathrm{D}=\mathrm{S} / 2 \mathrm{~d} 3 . \mathrm{ET} 5,0 \% \cdot \mathrm{Ga} \cdot 1.2 \mathrm{w}$

$\mathrm{E}=\mathrm{S} / 2 \mathrm{~d} 4 \cdot \mathrm{ET} 4,0 \% \cdot \mathrm{Ga} \cdot 1 \cdot 2 \mathrm{w}$

$\mathrm{F}=\mathrm{S} / 2 \mathrm{~d} 4 . \mathrm{ET} 5,0 \% \cdot \mathrm{Ga} \cdot 1.2 \mathrm{w}$

$\mathrm{G}=\mathrm{S} / 2 \mathrm{~d} 5 . \mathrm{ET} 4,0 \% \cdot \mathrm{Ga} \cdot 1 \cdot 2 \mathrm{w}$

$\mathrm{H}=\mathrm{S} / 2 \mathrm{~d} 5 . \mathrm{ET} 5,0 \% \cdot \mathrm{Ga} \cdot 1.2 \mathrm{w}$

$\mathrm{I}=\mathrm{S} / 2 \mathrm{~d} 6 . \mathrm{ET} 4,0 \% \cdot \mathrm{Ga} \cdot 1.2 \mathrm{w}$

$\mathrm{J}=\mathrm{S} / 2 \mathrm{~d}$.ET5,0\%.Ga.1.2w

$\mathrm{K}=\mathrm{S} / 2 \mathrm{~d} 3 \cdot \mathrm{ET} 2,5 \% \cdot \mathrm{Ga} \cdot 1 \cdot \mathrm{m} / 3$

Parameter pengamatan dari segi agronomi meliputi produktivitas per pohon per sadap $(\mathrm{g} / \mathrm{p} / \mathrm{s})$, sedangkan parameter pengamatan dari segi ekonomi meliputi : upah tenaga kerja penyadap, tenaga aplikasi stimulan, harga bahan stimulan dan harga jual karet. Untuk mengetahui kelayakan ekonomi sistem sadap, dilakukan analisis anggaran parsial dengan rumus sebagai berikut (Horton, 1982; Basuki, 2009):

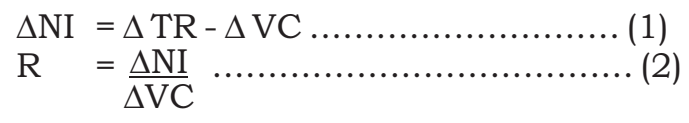

Dimana (Remaks) :

TR : Penerimaan total $(\mathrm{IDR} / \mathrm{Ha})=$ hasil $(\mathrm{Kg} / \mathrm{Ha}) \mathrm{x}$ harga hasil (IDR / Kg)

VC : Total biaya berubah (IDR $/ \mathrm{Ha})=$ kuantitas input yang digunakan 
(unit/Ha) x harga input (IDR / unit)

NI : Pendapatan bersih (IDR / Ha)

$\Delta \quad$ : Selisih atau margin

$\Delta \mathrm{NI}$ : Selisih pendapatan bersih sistem sadap selain kontrol dengan sistem sadap kontrol (IDR / Ha)

$\Delta \mathrm{TR}$ : Selisih penerimaan dari sistem sadap selain kontrol dengan sistem sadap kontrol (IDR / Ha)

$\Delta \mathrm{VC}$ : Selisih biaya variabel sistem sadap selain kontrol dengan sistem sadap kontrol (IDR / Ha)

$\mathrm{R} \quad$ : Rate of return (tingkat pengembalian)

Kriteria kelayakan ekonomi teknologi baru :

1. Jika $\Delta \mathrm{NI} \leq 0$, maka sistem sadap selain kontrol tidak layak secara ekonomi (ditolak)

2. Jika $\Delta \mathrm{NI}>0$, dan $\Delta \mathrm{VC} \leq 0$, maka sistem sadap selain kontrol layak secara ekonomi, (diterima)

3. Jika $\Delta \mathrm{NI}>0$, dan $\Delta \mathrm{VC}>0$, maka sistem sadap selain kontrol layak secara ekonomi jika $\mathrm{R}>1,0$.

Analisis anggaran parsial memungkinkan untuk mengetahui dampak dari perubahan dalam sistem produksi terhadap pendapatan bersih, tanpa harus mengetahui seluruh biaya produksi (Basuki, 2009). Analisis ini tidak menghitung semua biaya produksi secara lengkap, namun hanya biaya-biaya yang mengalami perubahan antara teknologi konvensional yang diterapkan dengan teknologi baru yang diusulkan sebagai perbaikan teknologi konvensional. Setiap perlakuan sistem sadap dilakukan analisis ekonomi menggunakan asumsi :

1. Populasi pohon $500 / \mathrm{Ha}$

2. Harga jual karet pada tahun 2016 : harga karet ekspor IDR 20.850,-/Kg dan harga karet lokal IDR 16.680,-/ Kg.

3. Upah penyadap IDR 17.040.000,- per tahun

4. Upah tenaga aplikasi stimulan cair etefon IDR 16.500,-/HK

5. Harga stimulan cair etefon $2,5 \%$ IDR $74.437,-$ / botol

\section{HASIL DAN PEMBAHASAN}

\section{Produktivitas Karet}

Hasil penelitian menunjukkan bahwa perlakuan sistem sadap $\mathrm{K}$ (S/2 d 3.ET 2,5\%.Ga.1.m/3) memiliki produktivitas tertinggi, sedangkan yang terendah adalah perlakuan I (S/2 d6.ET4,0\%.Ga.1.2w). Ada 3 perlakuan sistem sadap yang produktivitasnya mampu melampaui kontrol, yaitu perlakuan $\mathrm{K}, \mathrm{C}$, dan $\mathrm{F}$, sedangkan perlakuan sistem sadap lainnya masih lebih rendah dari kontrol. Produktivitas tiap sistem sadap dapat dilihat dalam Tabel 1.

Tabel 1. Produktivitas tiap sistem sadap (Kg/Ha/tahun)

Table 1. Productivity of each tapping system ( $\mathrm{Kg} / \mathrm{Ha}$ /years)

\begin{tabular}{|c|c|c|c|c|c|}
\hline $\begin{array}{l}\text { Perlakuan } \\
\text { Treatments }\end{array}$ & $\begin{array}{c}\text { Notasi sadap } \\
\text { Tapping notation }\end{array}$ & $\begin{array}{l}\text { Produksi } \\
(\mathrm{g} / \mathrm{p} / \mathrm{s}) \\
\text { Production } \\
(\mathrm{g} / \mathrm{t} / \mathrm{t})\end{array}$ & $\begin{array}{c}\text { Hari sadap } \\
\text { Tapping } \\
\text { days }\end{array}$ & $\begin{array}{l}\text { Produktivitas } \\
\text { rata-rata } \\
\text { (Kg/Ha/tahun) } \\
\text { Productivity } \\
\text { averages } \\
\text { (Kg/Ha/years) }\end{array}$ & $\begin{array}{c}\text { Marjin } \\
\text { produktivitas } \\
\text { terhadap } \\
\text { kontrol } \\
\text { Margin of } \\
\text { productivity } \\
\text { to control } \\
(\%)\end{array}$ \\
\hline A & S/2 d2 (Kontrol) & 14,9 & 180 & 1.339 & \\
\hline $\mathrm{B}$ & $\mathrm{S} / 2$ d3.ET2,5\%.Ga. $1.2 \mathrm{w}$ & 21,4 & 120 & 1.286 & $(3,96)$ \\
\hline $\mathrm{C}$ & $\mathrm{S} / 2$ d3.ET4,0\%.Ga. $1.2 \mathrm{w}$ & 24,6 & 120 & 1.478 & 10,81 \\
\hline $\mathrm{D}$ & S/2 d3.ET5,0\%.Ga. $1.2 \mathrm{w}$ & 19,7 & 120 & 1.179 & $(10,83)$ \\
\hline $\mathrm{E}$ & $\mathrm{S} / 2 \mathrm{~d} 4 . \mathrm{ET} 4,0 \% . \mathrm{Ga} \cdot 1.2 \mathrm{w}$ & 27,1 & 90 & 1.220 & $(10,09)$ \\
\hline $\mathrm{F}$ & $\mathrm{S} / 2 \mathrm{~d} 4 . \mathrm{ET} 5,0 \% . \mathrm{Ga} \cdot 1.2 \mathrm{w}$ & 30,9 & 90 & 1.390 & 4,18 \\
\hline $\mathrm{G}$ & S/2 d5.ET4,0\%.Ga.1.2w & 23,4 & 72 & 843 & $(35,68)$ \\
\hline $\mathrm{H}$ & S/2 d5.ET5,0\%.Ga. $1.2 \mathrm{w}$ & 28,0 & 72 & 1.008 & $(39,26)$ \\
\hline I & $\mathrm{S} / 2$ d6.ET4,0\%.Ga. $1.2 \mathrm{w}$ & 27,2 & 60 & 816 & $(51,88)$ \\
\hline $\mathrm{J}$ & S/2 d6.ET5,0\%.Ga.1.2w & 27,8 & 60 & 833 & $(62,01)$ \\
\hline $\mathrm{K}$ & $\mathrm{S} / 2$ d3.ET2,5\%.Ga.1.m/3 & 25,1 & 120 & 1.505 & 19,93 \\
\hline
\end{tabular}


Dari pengamatan produksi gram per pohon per sadap $(\mathrm{g} / \mathrm{p} / \mathrm{s})$, pada perlakuan penurunan frekuensi sadap mampu meningkatkan produksi. Hal tersebut tampak dari semua perlakuan frekuensi sadap lebih tinggi daripada kontrol (d2). Hasil penelitian ini, sejalan dengan pernyataan Nang et al., (2015) yang menyatakan bahwa penurunan frekuensi sadap dari d3 menjadi d4 dapat meningkatkan produksi. Herlinawati \& Kuswanhadi (2013) juga menyatakan bahwa klon PB 260 responsif terhadap penurunan frekuensi sadap akan terjadi peningkatan produksi.

Penurunan frekuensi sadap belum tentu meningkatkan produktivitas $(\mathrm{Kg} / \mathrm{Ha} /$ tahun) meskipun produksi tinggi karena juga dipengaruhi oleh jumlah hari sadapnya. Hal tersebut terjadi pada perlakuan sistem sadap F (S/2 d4.ET5,0\%.Ga.1.2w) dengan produksi senilai $30,9 \mathrm{~g} / \mathrm{p} / \mathrm{s}$ menghasilkan 1.390 $\mathrm{Kg} / \mathrm{Ha} /$ tahun, sedangkan perlakuan sistem sadap K (S/2 d3.ET2,5\%.Ga.1.m/3) dengan produksi $25,1 \mathrm{~g} / \mathrm{p} / \mathrm{s}$ menghasilkan 1.505 $\mathrm{Kg} / \mathrm{Ha} /$ tahun. Terjadi juga pada perlakuan sistem sadap A ( $\mathrm{S} / 2 \mathrm{~d} 2$ (Kontrol) dengan produksi hanya $14,9 \mathrm{~g} / \mathrm{p} / \mathrm{s}$, namun karena frekuensi sadapnya tinggi (hari sadap180 hari/tahun) sehingga menghasilkan produktivitas senilai $1.339 \mathrm{Kg} / \mathrm{Ha} /$ tahun. Nilai tersebut mendekati produktivitas perlakuan sistem sadap $\mathrm{F}$ yang frekuensi sadapnya lebih rendah 50\% (hari sadap 90 hari/tahun).
Jika dilihat dari pola produktivitas per bulannya, nampak bahwa perlakuan dengan frekuensi sadap rendah memiliki produktivitas yang secara dinamis lebih tinggi daripada kontrol (Gambar 1). Penurunan produktivitas terjadi saat memasuki musim gugur daun, sekitar Juli sampai dengan Oktober.

\section{Penggunaan Tenaga Kerja}

Pada frekuensi sadap d2, kebutuhan penyadap 0,50 per Ha, sedangkan pada d3 kebutuhan penyadap menjadi 0,33 per $\mathrm{Ha}$ (Susetyo, Ahmad, Widyasari, \& Syarifa, 2012). Dengan demikian, untuk frekuensi sadap d6, kebutuhan penyadap hanya 0,17 per Ha, nilai tersebut jauh lebih rendah daripada frekuensi sadap lainnya sehingga biaya tenaga penyadapnya juga lebih rendah, seperti ditampilkan dalam Tabel 2. Dari Tabel 2, nampak bahwa semakin rendah frekuensi sadap, maka kebutuhan tenaga penyadap semakin rendah, sehingga dapat menekan biaya melalui penurunan frekuensi sadap.

\section{Analisis Ekonomi}

Analisa ekonomi berbagai sistem sadap yang dilakukan dalam penelitian antara lain menghitung penerimaan, biaya, dan pendapatan bersih. Hasil analisis dapat dilihat dalam Gambar 2.

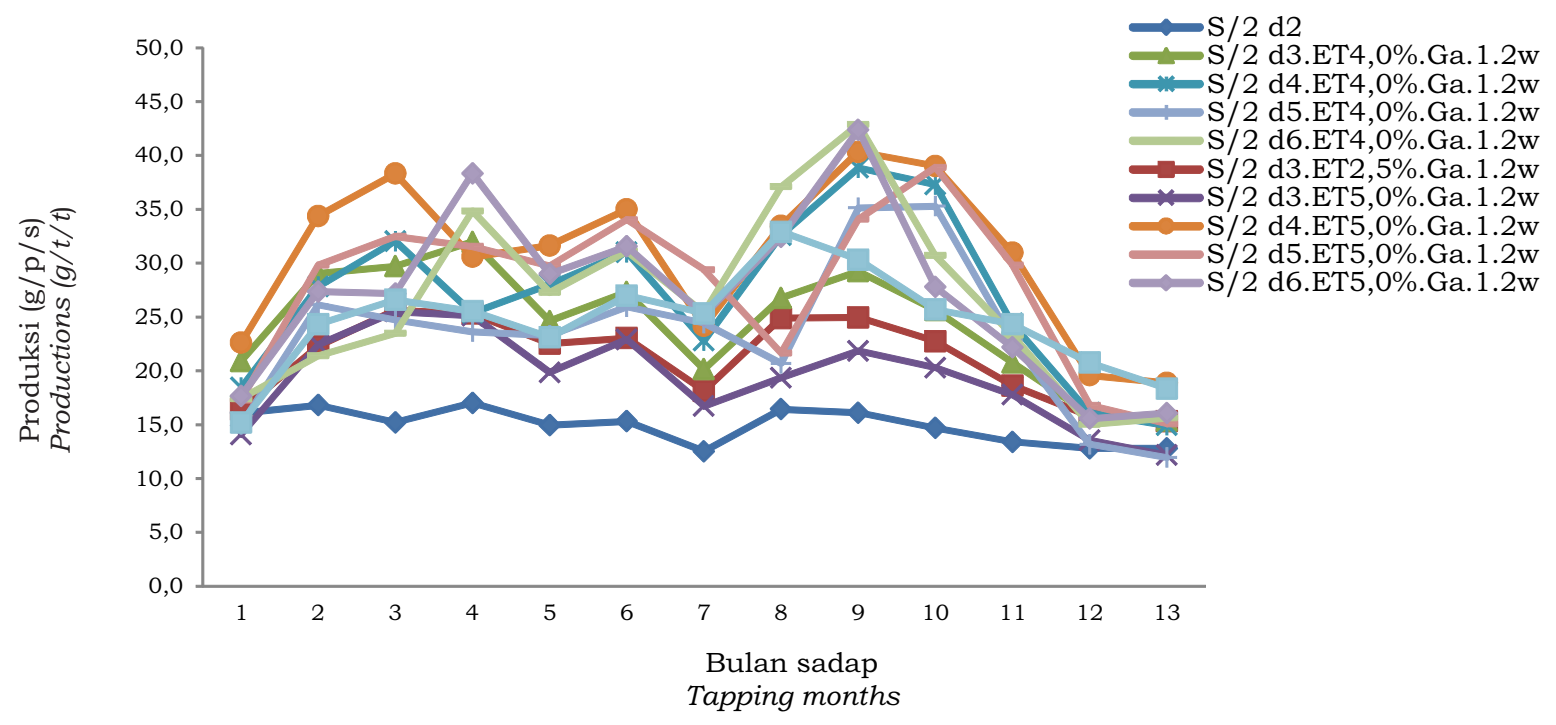

Gambar 1. Pola produktivitas pada berbagai perlakuan Figure 1. Productivity pattern on various treatment 
Tabel 2. Kebutuhan penyadap per Ha berdasarkan frekuensi sadap Table 2. Tapper requirement per Ha by tapping frequency

\begin{tabular}{cc}
\hline $\begin{array}{c}\text { Frekuensi sadap } \\
\text { Tapping frequencies }\end{array}$ & $\begin{array}{c}\text { Kebutuhan penyadap per } \mathrm{Ha} \\
\text { Tapper requirement per } \mathrm{Ha}\end{array}$ \\
\hline $\mathrm{S} / 2 \mathrm{~d} 2$ & 0,50 \\
$\mathrm{~S} / 2 \mathrm{~d} 3$ & 0,33 \\
$\mathrm{~S} / 2 \mathrm{~d} 4$ & 0,25 \\
$\mathrm{~S} / 2 \mathrm{~d} 5$ & 0,20 \\
$\mathrm{~S} / 2 \mathrm{~d} 6$ & 0,17 \\
\hline
\end{tabular}

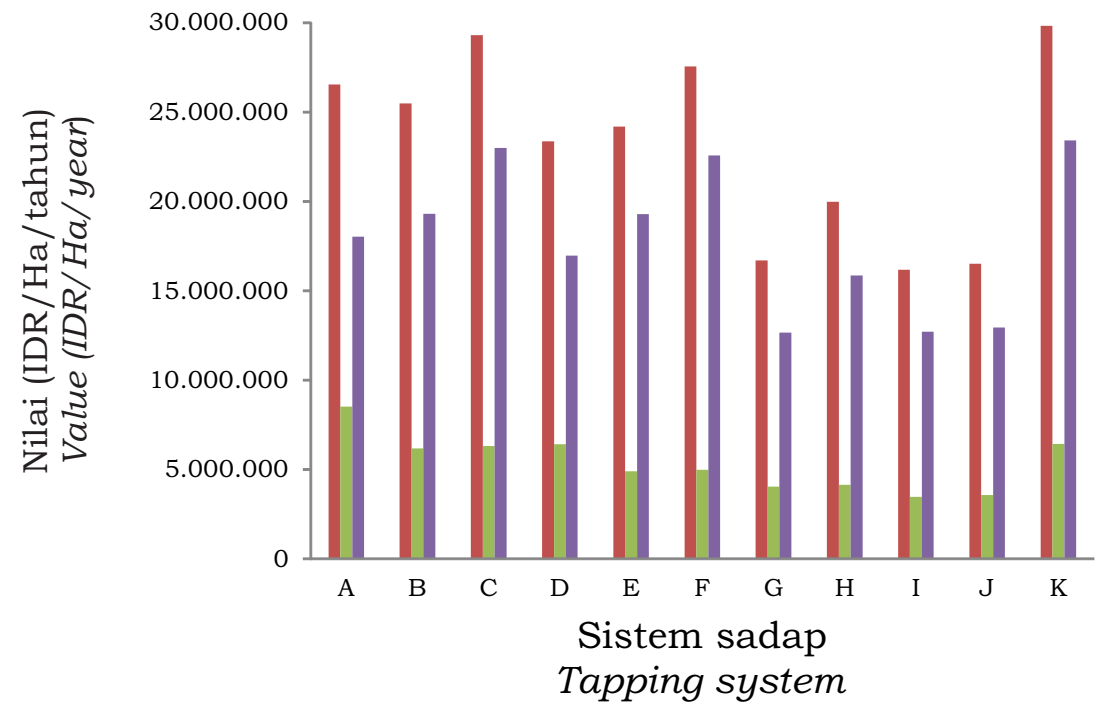

- Penerimaan (IDR/th) $₫$ Biaya penyadapan (IDR/th) $₫$ Pendapatan bersih (IDR/th)

Gambar 2. Hasil analisis ekonomi berbagai sistem sadap

Figure 2. Result of economic analysis of various tapping systems

Penerimaan merupakan hasil perkalian antara produktivitas (Kg/Ha/tahun) tiap sistem sadap dengan harga jual karet. Hasil penelitian menunjukkan bahwa perlakuan sistem sadap K (S/2d3.ET2,5\%Ga.1.m/3) menghasilkan penerimaan tertinggi sebesar IDR 29.835.346,-/tahun, seiring dengan produktivitasnya yang tertinggi jika dibandingkan dengan sistem lainnya, kemudian oleh perlakuan sistem sadap C dan F. Sedangkan yang terendah adalah perlakuan sistem sadap I (S/2d6.ET5,0\% .Ga.1.2w) hanya sebesar IDR 16.178.479,-/tahun, seiring dengan produktivitas yang paling rendah pula. Hal ini sejalan dengan penelitian Siregar, Lukman, Junaidi, Kuswanhadi dan Sutardi (1997) yang menyatakan bahwa penggunaan sistem sadap intensitas rendah yang disertai dengan aplikasi stimulansia etefon selain memberikan kenaikan produksi juga menghasilkan keuntungan yang lebih tinggi dibanding sistem sadap intensitas tinggi.
Biaya penyadapan yang dihitung dalam analisis adalah upah penyadap, upah tenaga aplikasi stimulan dan stimulansia, sedangkan biaya lainnya dianggap sama dan tetap. Biaya penyadapan tertinggi terjadi pada sistem sadap $\mathrm{S} / 2 \mathrm{~d} 2$ (kontrol), dan diikuti dengan perlakuan sistem sadap $\mathrm{K}$ (S/2 d3.ET2,5\% Ga.1.m/3), dan D (S/2 d3.ET5,0\%.Ga.1.2w). Sedangkan yang terendah terjadi pada perlakuan sistem sadap I (S/2d6.ET5\%Ga.1.2w) hanya senilai IDR 3.475.590,-/ Ha/tahun. Pada umumnya, penurunan biaya penyadapan terjadi karena pengurangan penggunaan hari kerja penyadap yang secara signifikan menurunkan biaya penyadapan. Semakin jarang kegiatan penyadapan, semakin rendah biayanya. Pada Tabel 3, tampak bahwa semakin rendah frekuensi sadap, semakin menurunkan biaya penyadapan. Hal tersebut sependapat dengan pernyataan Siregar, Suhendry dan Sumarmadji (2009), perubahan frekuensi sadap d3 menjadi d4 terbukti menurunkan biaya penyadapan. 
Pendapatan bersih merupakan selisih penerimaan dengan biaya penyadapan. Pendapatan bersih tertinggi pada perlakuan sistem sadap K (S/2d3.ET2,5\% Ga.1.m/3), diikuti dengan perlakuan C (S/2 d3.ET4,0\%.Ga.1.2w) dan F (S/2 d4.ET5,0\%.Ga.1.2w). Sedangkan yang terendah adalah perlakuan sistem sadap G (S/2 d5.ET4,0\%.Ga.1.2w). Pada perlakuan sistem sadap K (S/2 d3.ET2,5\% Ga.1.m/3), ternyata unggul meskipun memerlukan biaya yang tinggi setelah kontrol $(\mathrm{S} / 2 \mathrm{~d} 2)$, karena didukung oleh produktivitas dan penerimaan yang tertinggi. Pada masingmasing perlakuan sistem sadap menghasilkan penurunan biaya dan kenaikan pendapatan bersih terhadap kontrol yang bervariasi yang dapat dilihat dalam Tabel 3.

Perlakuan frekuensi sadap d6 mampu menurunkan biaya penyadapan $58 \%$ - 59\% terhadap kontrol, dan mengakibatkan penurunan pendapatan bersih hingga $28-30 \%$ terhadap kontrol. Perlakuan frekuensi sadap d3 (perlakuan B, $\mathrm{C}$, dan $\mathrm{K})$, hanya menurunkan biaya penyadapan 25-28\% terhadap kontrol, namun mampu menghasilkan pendapatan bersih $7 \%$ - 30\% terhadap kontrol, sedangkan perlakuan sistem sadap D (S/2 d3.ET 5, 0\%.Ga.1.2w) menghasilkan penurunan pendapatan bersihnya hingga 6\% terhadap kontrol. Dalam Tabel 3 menunjukkan bahwa frekuensi sadap d5, d6 dan khususnya S/2 d3.ET5,0\%.Ga.1.2w, meskipun mampu menurunkan biaya penyadapan namun berdampak menurunkan pendapatan bersih terhadap kontrol (d2) sehingga kurang prospektif untuk diterapkan.

\section{Analisis Anggaran Parsial}

Analisis anggaran parsial (partial budget analysis) ditujukan untuk melihat sistem sadap yang prospektif dan layak untuk dikembangkan. Hasil analisis anggaran parsial masing-masing sistem sadap ditampilkan pada Tabel 4.

Pada panel BO, diperoleh hasil bahwa semua sistem sadap mampu menekan biaya lebih rendah daripada kontrol (S/2d2) melalui penghematan tenaga kerja penyadap karena intensitas sadapnya lebih jarang daripada d2 (kontrol), yang ditunjukkan dengan nilai $\Delta \mathrm{VC} \leq 0$. Untuk nilai $\Delta \mathrm{NI}>0$ dicapai oleh perlakuan sistem sadap B, C, E, F dan K. Perlakuan sistem sadap K (S/2d3.ET.2,5\%.Ga.1. m/3) memiliki nilai $\Delta \mathrm{NI}$ tertinggi, yang artinya sistem sadap $\mathrm{K}$ mampu menghasilkan pendapatan bersih paling tinggi dibandingkan sistem sadap lainnya. Dengan demikian, perlakuan sistem sadap $\mathrm{B}, \mathrm{C}, \mathrm{E}, \mathrm{F}$ dan $\mathrm{K}$ masuk dalam kriteria $\Delta \mathrm{NI}>0$ dan $\Delta \mathrm{VC} \leq 0$ sehingga sistem sadap tersebut dapat diadopsi atau diterima untuk diterapkan lebih lanjut. Sejalan dengan pendapat Horton (1982) bahwa jika pendapatan bersih (NI) meningkat dan biaya variabel sama atau lebih rendah, maka teknologi baru sebaiknya diterima karena jelas lebih menguntungkan daripada teknologi konvensional yang sudah ada

Tabel 3. Penurunan biaya dan kenaikan pendapatan bersih terhadap kontrol pada berbagai sistem sadap

Table 3. Decrease of cost and increase in net revenue to controls at various tapping systems

\begin{tabular}{clcc}
\hline $\begin{array}{c}\text { Perlakuan } \\
\text { Treatments }\end{array}$ & \multicolumn{1}{c}{$\begin{array}{c}\text { Notasi sadap } \\
\text { Tapping notation }\end{array}$} & $\begin{array}{c}\text { Biaya } \\
\text { Cost } \\
(\%)\end{array}$ & $\begin{array}{c}\text { Pendapatan bersih } \\
\text { Net revenue } \\
(\%)\end{array}$ \\
\hline A & S/2 d2 (Kontrol) & - & - \\
B & S/2 d3.ET2,5\%.Ga.1.2w & $\downarrow 28$ & $\uparrow$ \\
C & S/2 d3.ET4,0\%.Ga.1.2w & $\downarrow 26$ & $\uparrow 28$ \\
D & S/2 d3.ET5,0\%.Ga.1.2w & $\downarrow 25$ & $\downarrow$ \\
E & S/2 d4.ET4,0\%.Ga.1.2w & $\downarrow 43$ & 6 \\
F & S/2 d4.ET5,0\%.Ga.1.2w & $\downarrow 41$ & $\uparrow$ \\
G & S/2 d5.ET4,0\%.Ga.1.2w & $\downarrow 53$ & $\downarrow 30$ \\
H & S/2 d5.ET5,0\%.Ga.1.2w & $\downarrow 51$ & $\downarrow 12$ \\
I & S/2 d6.ET4,0\%.Ga.1.2w & $\downarrow 59$ & $\downarrow 30$ \\
J & S/2 d6.ET5,0\%.Ga.1.2w & $\downarrow 58$ & $\downarrow 28$ \\
K & S/2 d3.ET2,5\%.Ga.1.m/3 & $\downarrow 25$ & \\
\hline
\end{tabular}


Tabel 4. Hasil analisis anggaran parsial pada panel BO

Table 4. Results of partial budget analysis on the BO panel (Bark Original)

\begin{tabular}{|c|c|c|c|c|}
\hline $\begin{array}{c}\text { Sistem sadap } \\
\text { Tapping systems }\end{array}$ & $\begin{array}{c}\text { Notasi sadap } \\
\text { Tapping notation }\end{array}$ & $\begin{array}{l}\Delta \mathrm{VC} \\
\text { (IDR) }\end{array}$ & $\begin{array}{l}\Delta \mathrm{NI} \\
\text { (IDR) }\end{array}$ & $\mathrm{R}$ \\
\hline A & $\mathrm{S} / 2 \mathrm{~d} 2$ (kontrol) & - & - & - \\
\hline B & $\mathrm{S} / 2 \mathrm{~d} 3 . \mathrm{ET} 2,5 \% . G a .1 .2 \mathrm{w}$ & $(2.343 .757)$ & 1.287 .879 & $(0,5)$ \\
\hline $\mathrm{C}$ & $\mathrm{S} / 2 \mathrm{~d} 3 . \mathrm{ET} 4,0 \% . \mathrm{Ga} .1 .2 \mathrm{w}$ & $(2.204 .410)$ & 4.962 .588 & $(2,3)$ \\
\hline $\mathrm{D}$ & $\mathrm{S} / 2$ d3.ET5,0\%.Ga. $1.2 \mathrm{w}$ & $(2.111 .513)$ & $(1.061 .323)$ & 0,5 \\
\hline $\mathrm{E}$ & $\mathrm{S} / 2 \mathrm{~d} 4 . \mathrm{ET} 4,0 \% . \mathrm{Ga} .1 .2 \mathrm{w}$ & $(3.624 .410)$ & 1.272 .825 & $(0,4)$ \\
\hline $\mathrm{F}$ & $\mathrm{S} / 2 \mathrm{~d} 4 . \mathrm{ET} 5,0 \% . \mathrm{Ga} .1 .2 \mathrm{w}$ & (3.531.513) & 4.542 .040 & $(1,3)$ \\
\hline G & $\mathrm{S} / 2 \mathrm{~d} 5 . \mathrm{ET} 4,0 \% . \mathrm{Ga} .1 .2 \mathrm{w}$ & $(4.476 .410)$ & $(5.363 .166)$ & 1,2 \\
\hline $\mathrm{H}$ & $\mathrm{S} / 2$ d5.ET5,0\%.Ga. $1.2 \mathrm{w}$ & $(4.383 .513)$ & $(2.172 .802)$ & 0,5 \\
\hline I & $\mathrm{S} / 2$ d6.ET4,0\%.Ga. $1.2 \mathrm{w}$ & $(5.044 .410)$ & $(5.321 .639)$ & 1,1 \\
\hline $\mathrm{J}$ & S/2d6.ET5,0\%.Ga.1.2w & $(4.951 .513)$ & $(5.076 .200)$ & 1,0 \\
\hline $\mathrm{K}$ & $\mathrm{S} / 2$ d3.ET2,5\%.Ga.1.m/3 & $(2.095 .635)$ & 5.386 .452 & $(2,6)$ \\
\hline
\end{tabular}

(kontrol), dan tidak perlu dilakukan perhitungan $\mathrm{R}$.

Hasil penelitian menunjukkan bahwa penurunan frekuensi sadap belum tentu meningkatkan produktivitas meskipun menghasilkan produksi yang tinggi, namun dapat menurunkan biaya penyadapan melalui penurunan penggunaan hari kerja penyadap karena hari sadapnya juga menurun.

Melalui berbagai sudut pandang dari segi teknis agronomi dan ekonomi, diperoleh hasil bahwa :

1. Frekuensi sadap d3 tetap paling unggul dari segi agronomi dan ekonomi, terutama S/2d3.ET2,5\%.Ga.1.m/3 karena mampu menghasilkan produktivitas dan pendapatan tertinggi. Selain itu, sistem sadap S/2d3.ET $2,5 \%$. Ga. $1.2 \mathrm{w}$ d a n $\mathrm{S} / 2 \mathrm{~d} 3 . \mathrm{ET} 4,0 \%$.Ga.1.2w juga prospektif untuk diterapkan.

2. Jika berorientasi menurunkan biaya, namun menghasilkan produktivitas yang tidak berbeda jauh dengan $\mathrm{d} 2$, maka dapat dipilih d3 dan d4. Frekuensi sadap d4 mampu menjadi solusi jika terjadi kekurangan penyadap, dan masih dapat menghasilkan pendapatan bersih lebih tinggi $7 \%$ sampai dengan $25 \%$ dari d2 (kontrol), jika dibandingkan dengan frekuensi sadap d5 dan d6 yang justru lebih rendah produktivitasnya dan pendapatan bersihnya, sehingga
$\mathrm{S} / 2$ d4.ET4,0\%.Ga.1.2w dan S/2d4.ET5,0\%.Ga.1.2w prospektif untuk diterapkan.

3. Jika berorientasi menurunkan biaya saja, penurunan frekuensi sadap hingga d6, paling mampu menekan biaya $58 \%$ sampai dengan 59\% dari kontrol, namun pendapatan bersihnya juga turun $28 \%$ sampai dengan 30\% terhadap d2 (kontrol) dan produktivitasnya lebih rendah sekitar $40 \%$ dari d2 sehingga kurang prospektif untuk diterapkan.

\section{KESIMPULAN}

Penelitian secara komprehensif berbagai sistem sadap di panel BO telah dilakukan dengan hasil bahwa yang prospektif untuk diterapkan adalah pada frekuensi sadap d3 yaitu sistem sadap $\mathrm{S} / 2$ d 3. E T $2,5 \%$. G a . 1. m / 3, S / 2 d 3.E T 2, 5\%.Ga.1.2 w dan S/2 d3.ET4,0\%.Ga.1.2w, serta pada frekuensi sadap d4 yaitu sistem sadap $\mathrm{S} / 2$ d 4.E T 4,0\%.Ga.1.2w d a n S/2 d4.ET5,0\%.Ga.1.2w. Penurunan frekuensi sadap yang berdampak pada penurunan biaya ternyata belum tentu menghasilkan pendapatan bersih yang tinggi, jika tidak didukung dengan produktivitas yang tinggi seperti terjadi pada d5, d6 dan sistem sadap S/2 d3.ET5,0\%.Ga.1.2w. Penurunan frekuensi sadap terbukti mampu menaikkan produksi namun belum tentu meningkatkan produktivitasnya karena dipengaruhi jumlah hari sadap. Dengan demikian, 
$\mathrm{m} \mathrm{e} \mathrm{s} \mathrm{k} \mathrm{i} \mathrm{p} \mathrm{u} \mathrm{n} \mathrm{s} \mathrm{i} \mathrm{s} \mathrm{t} \mathrm{e} \mathrm{m} \mathrm{s} \mathrm{a} \mathrm{d} \mathrm{a} \mathrm{p}$ S/2d3.ET2,5\%.Ga.1.m/3 paling prospektif untuk diterapkan, tidak menutup kemungkinan untuk menerapkan frekuensi sadap d4 dalam mengatasi kelangkaan tenaga kerja penyadap dan menekan biaya penyadapan dengan produktivitas yang tidak terlalu jauh berbeda dengan d3.

\section{DAFTAR PUSTAKA}

Basuki, R.S. (2009). Analisis kelayakan teknis dan ekonomis teknologi budidaya bawang merah dengan benih biji botani dan benih umbi tradisional. Jurnal Hortikultura, 19(2), 213

${ }^{a}$ Herlinawati, E., \& Kuswanhadi. (2012). Pengaruh penggunaan stimulan gas terhadap produksi dan karakter fisiologi klon BPM 24. Jurnal Penelitian Karet, 30(2), 100-107. Doi : 10.22302/ppk.jpk.v30i2.126

${ }^{b}$ Herlinawati, E., \& Kuswanhadi. (2012). Respon beberapa klon karet seri IRR terhadap frekuensi stimulan etefon yang berbeda. Prosiding Konferensi Nasional Karet (p. 221-227). Yogyakarta, Indonesia: Pusat Penelitian Karet.

Herlinawati, E., \& Kuswanhadi. (2013). Aktivitas metabolisme beberapa klon karet pada berbagai frekuensi sadap dan stimulasi. Jurnal Penelitian Karet, 31 ( 2 ), $110-116$. D o i : 10.22302/ppk.jpk.v31i2.138

Horton, D. (1982). Partial budget analysis for on-farm potato research : International Potato Centre (CIP). Technical Information Bulletin, 16, 9-11.

Nang, N., Hai, T.V., Thanh, D.K., Luyen, P.V., Tuan, T.V., Thai, N.V., Viet, N.Q., $\&$ Thui, K.T. (2015). The yield and latex physiological parameters on $\mathrm{d} 3$ and $\mathrm{d} 4$ tapping system of PB 260 Clone at Southeast Region in Vietnam. Proceedings International Rubber Conference. Ho Chi Minh City, Vietnam: IRRDB-RRIV.
Pusat Penelitian Karet. (2016). Kajian pengaturan portofolio komoditas berbasis daya saing karet pada perkebunan karet lingkup Perusahaan X. Bogor, Indonesia: Puslit Karet.

Rodrigo, V.H.L. (2007). Adoption of different tapping systems in the rubber industry of Sri Lanka with special reference to low frequency tapping. Journal of the Rubber Research Institute of Sri Lanka, $88,1-21$.

Rouf, A., Nugrahani, M.O. \& Aji, Y.B.S. (2016). Tantangan perkebunan karet untuk mengatasi kelangkaan tenaga penyadap di era Masyarakat Ekonomi ASEAN (MEA). Prosiding Seminar Hasil Penyuluhan dan Komunikasi Pembangunan (p. 227-234). Yogyakarta, Indonesia: Universitas Gadjah Mada.

Siregar, T.H.S., Lukman, Junaidi, U., Kuswanhadi., \& Sutardi. (1997). Sistem penyadapan yang efisien di perkebunan karet. Prosiding Apresiasi Teknologi Peningkatan Produksi Lahan Perkebunan Karet (p. 33 - 53). Medan, Indonesia: Pusat Penelitian Karet.

Siregar, T.H.S., Suhendry, I., \& Sumarmadji. (2009). Manajemen sistem eksploitasi menghadapi dinamika harga karet dan biaya. Makalah Pertemuan Teknis Eksploitasi Tanaman Karet. Medan, Indonesia: Pusat Penelitian Karet.

Sumarmadji., Junaidi., \& Atminingsih. (2009). Perkembangan sistem eksploitasi dalam upaya pencapaian produktivitas optimal. Warta Perkaretan, 28(2), 61-62.

Susetyo, I., Rouf, A., Widyasari, T., \& Syarifa, L.F. (2012). Studi kesesuaian lahan dan sosial ekonomi untuk pengembangan karet Perum Perhutani III, Provinsi Jawa Barat. Laporan Pelayanan. Salatiga, Indonesia: Balai Penelitian Getas.

Widyasari, T., Hartono, S., \& Irham. (2015). Peremajaan optimal tanaman karet di PT Perkebunan Nusantara IX (Analisis simulasi pada kebun Getas). Jurnal Penelitian Karet, 33(1), 47-56. Doi : 10.22302/ppk.jpk.v33i1.170 